\title{
CRUISE SHIPS AND URBAN MOBILITY IN MEDITERRANEAN SPAIN
}

\author{
ALEJANDRO L. GRINDLAY* \& SERGIO MARTÍNEZ-HORNOS \\ Department of Urban and Regional Planning, University of Granada, Spain
}

\begin{abstract}
Prior to the current COVID-19 pandemic, the tourist industry and, in particular, its cruise shipping element, was one the leading economic sectors of the Spanish economy. Traditionally, port terminals specializing in cruise shipping generated localized traffic peaks that impacted on the management of urban mobility in port cities, and this created a major difficulty in the city-port relationship. The health crisis caused by COVID-19 has had a very strong impact on the cruise sector which reached its maximum in the volume of passengers in 2019 and practically disappeared during the following year, with reduction rates higher than ninety percent. Through indicators analysis, this paper will examine the impacts of cruise shipping on urban mobility in Spanish Mediterranean port cities (Alicante, Almeria, Barcelona, Malaga, Palma de Mallorca, Tarragona and Valencia), and on the mobility planning measures proposed and developed to mitigate these impacts. Due to data availability, the year 2018 will be considered to evaluate the general impact of cruise traffic on urban population and urban mobility characteristics. With an expected stabilization of the COVID-19 pandemic, the Spanish tourist industry and the associated cruise shipping activity face the greatest challenge in their history: reactivation. International sanitary measures and mass vaccination are allowing a new normality to emerge. Therefore, the reopening of services associated with the cruise shipping industry is starting to be announced, with the appropriate promotion of public policies, in order to achieve the sector's revitalization. This expected return to pre-pandemic figures for cruise shipping traffic is a challenging scenario in Spanish Mediterranean port-cities, where the indicated measures and new urban mobility management for the future should be explored and considered.
\end{abstract}

Keywords: COVID-19, cruise shipping, Mediterranean Spain, port-city relationships, public policies, urban mobility.

\section{INTRODUCTION: CRUISE SHIPPING INDUSTRY IN SPAIN}

Given its peninsular character and its archipelagos, Spain is a country with an extensive coastline, hence, it is also a country with a large number of ports and port-cities. Additionally, its diverse Atlantic/Mediterranean coastal climates have traditionally given rise to a significant 'sun and beach' tourist industry. This was increasingly complemented by the growing cruise shipping element which, prior to the current COVID-19 pandemic, was one the leading commercial sectors of the Spanish economy. The volume of tourism in 2019 in Spain had reached $12.4 \%$ of GDP, and $12.9 \%$ of total employment [1]. It had the second highest number of cruise ship passengers in Europe, with more than 10 million in 2018/19, and the contribution of the cruise shipping sector to the Spanish economy represented $10.9 \%$ of the GDP of the total national tourism sector, with particular relevance for the ports of Barcelona, the Balearic Islands and the Canary Islands [2].

With respect to their organization, bigger ports are state owned and managed by port authorities. Most cruise ship traffic is concentrated in these larger ports, however there is also a high number of marinas distributed along the coastline, offering tourist services for smaller cruise ships. The historical development of bigger ports servicing larger cities has meant that, despite their positive economic impact, the localized traffic peaks generated by port terminals

*ORCID: http://orcid.org/0000-0001-5176-0550 
specializing in cruise shipping affected the municipal management of urban mobility and created a major difficulty in the city/port relationship, along with other diverse issues [3].

In general, cruise shipping and cruise ports activities have been a growing sector in recent decades. This sector remained unaffected by the global financial crisis of 2008/09 which had a major impact on other maritime shipping, and continued to enjoy a steadily rising number of passengers. The Mediterranean was also a leading cruising region, perceived as the alternative to the mature Caribbean [4]. However, it has been severely affected by the COVID-19 pandemic and this health crisis has had a particularly strong impact on the Spanish cruise sector.

Thus, the cruise industry has faced 'a sharp economic decline' and, since mid-march 2020 and continuing through this year (2021), it has been devastated, with widespread disruption and cancellations affecting millions of cruise passengers; flights and cruises were cancelled, entire crews and passengers were under quarantine, borders closed and, in many tourist areas hotels, restaurants, resorts, etc. were forced to close for months. Previous economic tourism figures in Spain give an idea of the magnitude of the crisis. Despite the high level of uncertainty, it is also expected that recovery will begin in upcoming months. The widespread uptake of the vaccination process is expected to secure the sector's recovery, as the intention to take a cruise greatly depends on it $[5,6]$.

The purpose of this paper is to assess, through indicators analysis, the past and future expected impacts of cruise shipping on urban mobility in some of the larger Mediterranean Spanish port-cities, focusing specifically on those of Alicante, Almeria, Barcelona, Malaga, Palma de Mallorca, Tarragona and Valencia, given their more homogeneous characteristics. In order to achieve this, the next section will analyse the recent evolution of cruise passenger traffic in these port-cities. Next, the general impact of cruise traffic on urban population and urban mobility characteristics will be evaluated. The mobility planning measures proposed and developed in the respective port-cities in order to mitigate these impacts will be also examined.

It is particularly interesting to study this situation at the anticipated end of this deep crisis because, due to the control of the COVID-19 pandemic, the Spanish tourist industry and its associated cruise shipping activity is facing the greatest challenge in their recent history. Given the international sanitary measures and mass vaccination processes, a new normality is emerging, and the re-opening of services associated with the cruise shipping industry is in progress. Finally, this expected return to pre-pandemic figures for cruise shipping traffic presents a challenge for Spanish Mediterranean port-cities, where the indicated measures and new urban mobility management for the future need to be explored and considered.

\section{CRUISE PASSENGER EVOLUTION IN SPANISH PORT-CITIES}

\subsection{Figures for cruise passengers utilizing Spanish and Mediterranean Spanish ports}

As previously indicated, cruise passenger numbers in general, and in Spanish ports in particular, have been steadily growing in the decades up to 2019. In this year they reached their maximum, with more than ten and half million passengers. With respect to total Spanish ports, Spanish Mediterranean ports (Fig. 1) regularly have more than two thirds of the passengers, reaching a record figure of 7,187,493 cruise passengers, with the operation of 2,454 cruise ships in 2019. However, during 2020 it had an inverse proportion, due to the initial recovery of the Canary Islands ports of las Palmas and Tenerife, with a total traffic of only 450,408 passengers in 177 cruise ships (see Table 1). 


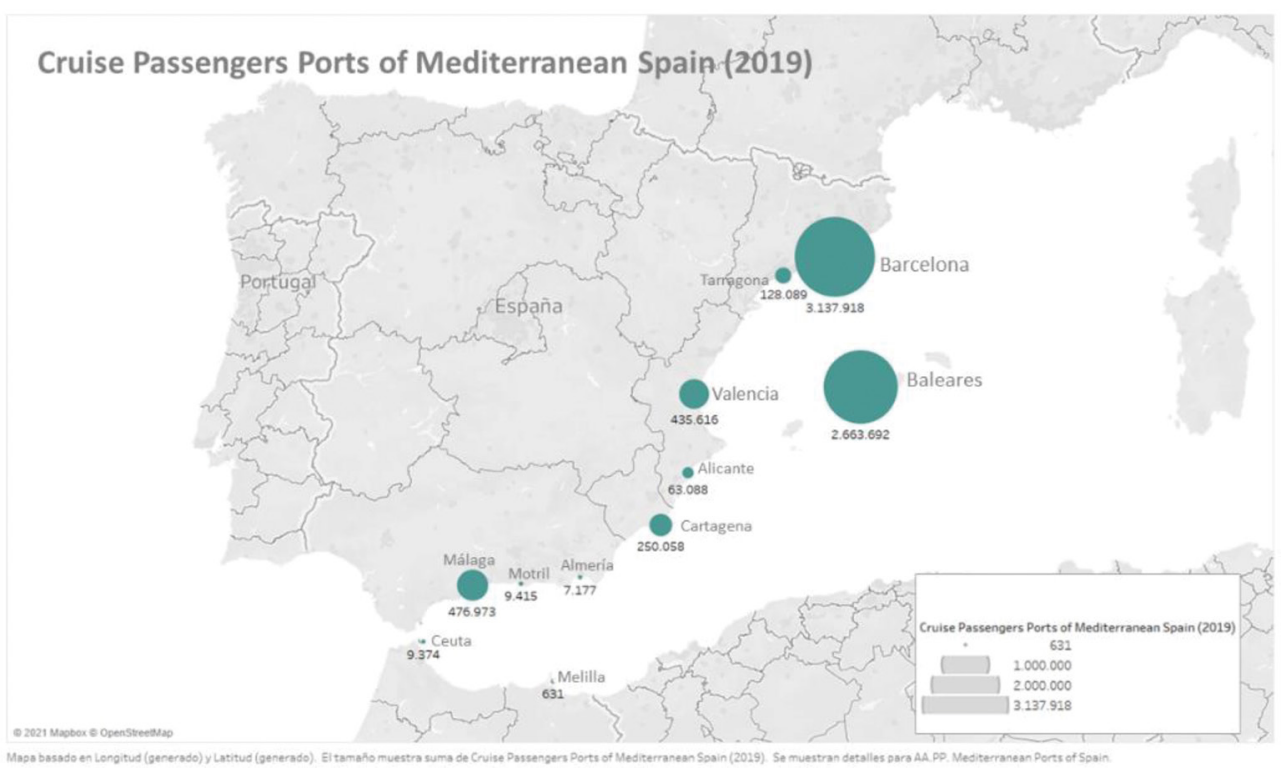

Figure 1: Cruise passenger volume in Mediterranean Spain ports in 2019.

Table 1: Cruise passenger evolution in Spain ports and Mediterranean Spain ports. (source: Authors based on Puertos del Estado [7]).

\begin{tabular}{llll}
\hline Year & $\begin{array}{l}\text { Total cruise passengers } \\
\text { ports of Spain }\end{array}$ & $\begin{array}{l}\text { Cruise passengers ports } \\
\text { of Mediterranean Spain }\end{array}$ & $\%$ \\
\hline 2009 & $6,063,444$ & $4,280,462$ & 70.59 \\
2010 & $7,184,213$ & $5,058,389$ & 70.41 \\
2011 & $8,020,150$ & $5,533,840$ & 69.00 \\
2012 & $7,596,784$ & $5,044,666$ & 66.41 \\
2013 & $7,671,458$ & $5,221,088$ & 68.06 \\
2014 & $7,711,411$ & $4,944,768$ & 64.12 \\
2015 & $8,646,576$ & $5,561,139$ & 64.32 \\
2016 & $8,693,871$ & $5,838,484$ & 67.16 \\
2017 & $9,281,923$ & $6,185,916$ & 66.64 \\
2018 & $10,170,379$ & $6,880,751$ & 67.65 \\
2019 & $10,664,581$ & $7,187,493$ & 67.40 \\
2020 & $1,374,241$ & 450,408 & 32.78 \\
\hline
\end{tabular}

Among Spanish Mediterranean port authorities Barcelona and the Balearic Islands, are highlighted. Of the five Balearic ports (Palma, Alcudia, Mahon, Ibiza, and La Savina), Palma de Mallorca accounts for $84 \%$ of cruise passenger traffic. 
2.2 Impact of COVID-19 pandemic on Cruise passenger evolution in Spanish Mediterranean ports

Spain banned cruise ships from docking in its ports in June 2020 as the COVID-19 pandemic ripped through Europe. As can be seen in Fig. 2, the devastating effect of the pandemic on this industry has led to the disappearance of practically all cruise ship traffic during 2020, with reduction rates higher than ninety percent in all Spanish Mediterranean ports (see Table 2).

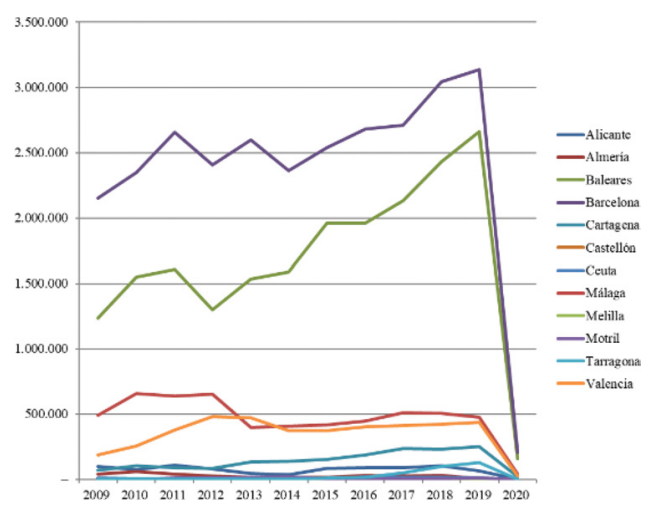

Figure 2: Cruise passenger evolution in Spanish Mediterranean ports and the COVID-19 crisis.

Table 2: COVID-19 crisis impact on cruise passenger evolution in Spanish Mediterranean ports. (Source: Authors based on Puertos del Estado [7]).

\begin{tabular}{|c|c|c|c|c|c|c|}
\hline \multirow[t]{2}{*}{$\begin{array}{l}\text { Mediterranean port } \\
\text { authorities of Spain }\end{array}$} & \multicolumn{2}{|c|}{$\begin{array}{l}\text { Cruise Passengers } \\
\text { (thousand) }\end{array}$} & \multirow[t]{2}{*}{ Variation $\%$} & \multicolumn{2}{|c|}{$\begin{array}{l}\text { Cruise passengers } \\
\text { (thousand) }\end{array}$} & \multirow[t]{2}{*}{ Variation $\%$} \\
\hline & 2018 & 2019 & & 2019 & 2020 & \\
\hline Barcelona & 3,042 & 3,138 & 3.15 & 3,138 & 203,86 & -93.50 \\
\hline Balearics & 2,430 & 2,664 & 9.61 & 2,664 & 156,76 & -94.12 \\
\hline Malaga & 507 & 477 & -6.00 & 477 & 40,17 & -91.58 \\
\hline Valencia & 422 & 436 & 3.34 & 436 & 26,29 & -93.97 \\
\hline Cartagena & 229 & 250 & 9.05 & 250 & 18,86 & -92.46 \\
\hline Tarragona & 98 & 128 & 30.52 & 128 & 1,46 & -98.86 \\
\hline Alicante & 101 & 63 & -37.38 & 63 & 2,41 & -96.18 \\
\hline Motril & 5 & 9 & 77.21 & 9 & 0,01 & -99.92 \\
\hline Ceuta & 16 & 9 & -40.90 & 9 & 0,00 & -100.00 \\
\hline Almeria & 29 & 7 & -75.58 & 7 & 0,59 & -91.75 \\
\hline Castellon & 1 & 5 & 861.62 & 5 & 0,00 & -100.00 \\
\hline Melilla & 0 & 1 & 71.47 & 1 & 0,00 & -100.00 \\
\hline TOTAL & 6,881 & 7,187 & 4.46 & 7,187 & 450 & -93.73 \\
\hline
\end{tabular}




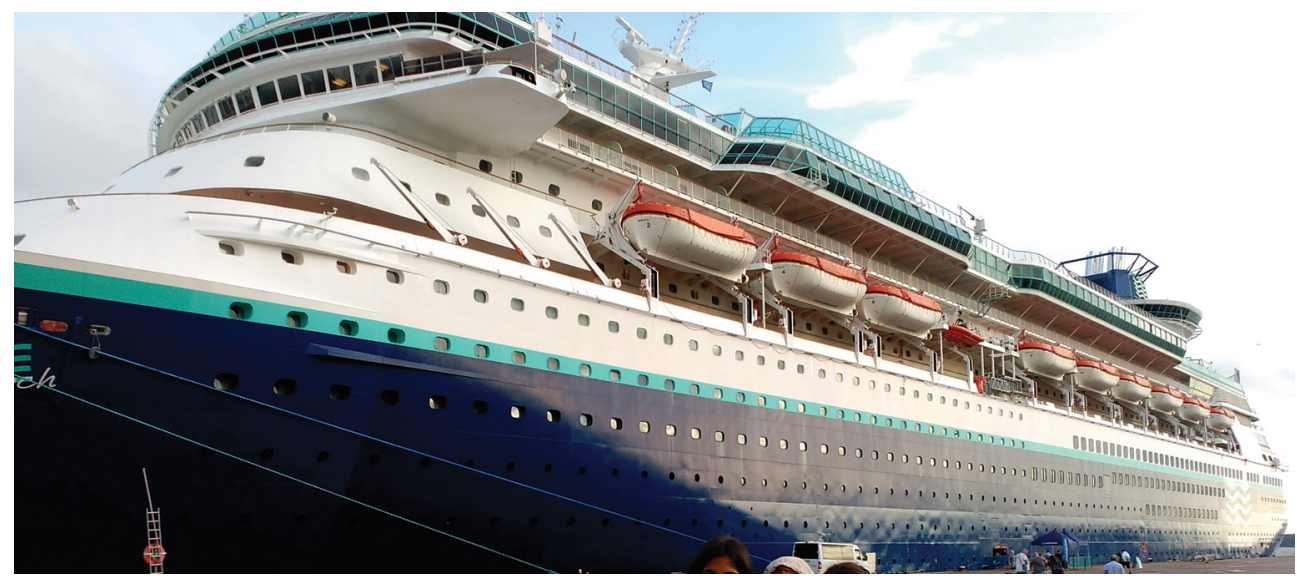

Figure 3: Monarch cruise ship of Pullmantur cruisers scrapped in July 2020 (Photo: A.L. Grindlay, Helsinky, 2017).

Despite this severe crunch, a progressive recovery is expected this year (2021), as will be shown in a later section, although some cruise ship companies will not recover after such a deep crisis (Pullmantur, C\&MV, FTI Cruises, Blount Small Ship Adventures, Jalesh Cruises, etc.) $[8]$.

\section{IMPACTS OF CRUISE SHIPPING ON URBAN MOBILITY}

Cruise shipping was considered the most dynamic sector of maritime transport [4] but, in addition to its economic benefits, this activity has also had some negative side effects. Its serious environmental impact has been proven to be even greater than its economic benefits. In the case of Croatia, the environmental costs were calculated to be up to seven times higher than the financial benefit to local communities [9].

In addition to the environmental problems affecting urban population, one of the main concerns from the port perspective, in order to maintain and increase its competitivity, is accessibility [10]. This is one of the most important issues for the city/port relationship as freight circulations are different from tourist movements, but both depend on port access and they are greatly affected by urban mobility [3].

\subsection{Cruise shipping social impact on Spanish Mediterranean port-cities}

The previous ever-increasing pressure of cruise shipping activity on the Mediterranean port cities has been evaluated, according to Rosas et al. [11], through indicators analysis.

In order to assess the different impact levels of cruise shipping on the Spanish Mediterranean port-cities, as a first approximation, the local population was compared with the total volume of cruise passengers. This ratio is a primary indicator and of great significance for the evaluation of their social impact [12]. Due to the requirement for homogenous data availability on urban and metropolitan mobility, from the twelve Spanish Mediterranean port cities only seven will be studied: Alicante, Almeria, Barcelona, Malaga, Palma de Mallorca, Tarragona and Valencia, and population figures for the year 2018 will be considered [13] (see Table 3).

As can be seen from Table 3, all the above-mentioned port-cities consists of important metropolitan areas, as they have followed a traditional process of coastal urban growth, with 


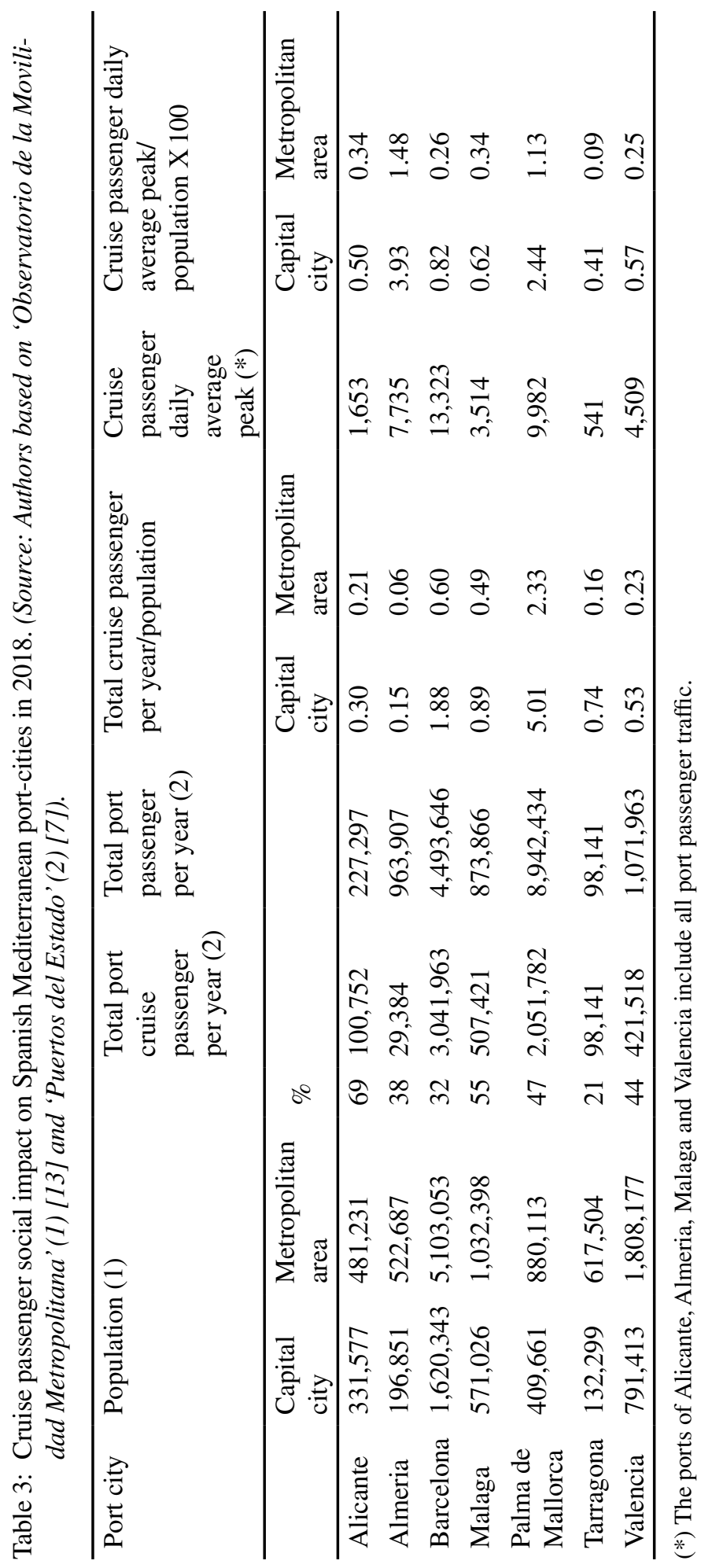


diverse population concentration levels of the capital city and their respective metropolitan areas (\%), which are higher in the cases of Alicante and Malaga.

Total port passenger traffic, with respect to port cruise passenger traffic, is the same only in the case of Tarragona and it is relatively higher in the cases of Barcelona and Malaga. It is more than double in the cases of Alicante and Valencia, due to their connections with the Balearic Islands, and it is extremely higher in the case of Almeria up to more than thirty times due to its connections with north African ports and the 'Gibraltar Straight Crossing' yearly operation.

As is shown in Table 3, the social impact of cruise shipping was especially relevant in the case of Palma de Mallorca city-port and less so in the case of Barcelona. Naturally this impact is reduced on taking into account metropolitan area population, though not in Mallorca's case, where its primary tourist orientation is apparent.

With the aim of measuring approximate cruise passenger traffic peaks in the port-cities studied the daily average has been calculated from monthly passenger data available from port authorities' statistics [7], however these peaks are usually higher than estimated. In fact, in Malaga it is three times higher than the considered average, with up to 10,000 cruise passengers a day, as was determined in a previous study [3]. Given the availability of only total port passenger figures from the port authorities of Alicante, Almeria, Malaga and Valencia, these have been included in the port passenger traffic peak analysis, showing its high impact in the case of Almeria's city-port due to the previously mentioned connections with northAfrican ports. The high impact of the daily peak in cruise passenger traffic is also revealed in the case of Palma de Mallorca and similarly in the other port-cities in this study.

\subsection{Cruise shipping impact on urban mobility in Mediterranean Spain}

\subsubsection{Urban centrality: pedestrian orientation and inter-modality}

The historical development of all the studied Spanish Mediterranean port-cities entails a proximate location to their urban historic centres [14], which concentrate the cities' main tourist, commercial and leisure attractions at a reasonable walking distance from the port's cruise terminals. However, in some peak periods it causes the overcrowding of these centres by cruise passengers [15]. This is particularly relevant in the three most attractive Spanish Mediterranean cruise ports of Barcelona, Palma de Mallorca and Malaga, located adjacent to their city centres. Although port development has cause cruise port terminals to be more distant from the city centres, $2.4 \mathrm{~km}$ in the case of Malaga and 3.6 and $3.7 \mathrm{~km}$ in Barcelona and Mallorca respectively (estimated by Google Maps), these distances are walkable for active people. Valencia is the fourth port-city in terms of cruise passenger traffic and it was similarly developed in the past but, for defensive reasons during Medieval ages, the historical city arose $4 \mathrm{~km}$ inland from the coastline, resulting in it being nowadays the most distant historical city centre from the cruise port terminal of those cases studied $(5.3 \mathrm{~km})$.

This urban centrality is likewise relevant in the proximate location of the main nodes of public transport to the cruise port terminals, enabling inter-modality and promoting the use of these more sustainable systems to access the whole tourist, commercial and leisure metropolitan experience [15].

\subsubsection{Assessing impacts on urban mobility}

With the purpose of assessing the impacts of cruise shipping on urban mobility the passenger daily trips generated by these terminals affecting the urban and metropolitan mobility systems have been estimated. These are characterised by the Metropolitan Mobility Observatory 
[13] using the information from the different mobility studies and plans of each metropolitan area, indicating the number of total metropolitan trips in a typical business day, the average number of daily trips per person, and the existing modal share. Estimating an average number of 2.7 daily trips per cruise passenger, a number of cruise passenger daily trips has been calculated and the proportion of these trips in relation to the metropolitan mobility (Table 4).

As expected, the impact of cruise passenger traffic was higher in the case of Palma de Mallorca, followed by Barcelona, Malaga and Valencia. As has been observed in many cases, tourism activity has a relevant impact on the urban public transport system, as public transport is used extensively by tourists in urban destinations in contrast with rural destinations $[16,17]$. Although cruise ship tourists usually use pre-contracted transport services, some of them prefer to go on trips by themselves and therefore will have a certain impact on the usage of these systems but, as has been demonstrated, this impact will be lower in larger metropolitan areas with a well-developed public transport system such as in Barcelona [15].

The existing satisfactory muua share of Barcelona and, to a lesser degree of Valencia, reflects this limited impact in bigger metropolitan areas with highly developed public transport systems. However, as the table shows, in the case of Mallorca the impact is greater, not only because of the high proportion of estimated cruise passenger trips with respect to all metropolitan daily trips, but also because the reduced participation of the public transport system in their modal share will exacerbate the negative effects of new tourist cruise passenger flows.

\subsubsection{Impact of COVID-19 on the use of public transport systems}

The impact of COVID-19 on the use of public transport systems is demonstrated well in the Moovit's web report displayed in Fig. 4. This report, updated daily, shows Moovit's app usage for the previous 7 days in each city, and is compared with a typical week before the outbreak began (the week prior to January 15th, 2020).

In the chart the available cities of Barcelona, Malaga, Mallorca and Valencia have been included. The severe effect of lockdown since mid-March to mid-July 2020, and the progressive recovery of public transport usage is highlighted. This usage is higher, and even positive, in the case of Mallorca, as this city-port recovered part of its tourism activity during last summer, and now it is also reporting a positive trend and recovery of the use of public transport systems at the end of this 2021 spring.

\subsection{Mobility plans and European Mobility Projects in Spanish Mediterranean port-cities}

In order to access state aid for public transport policies, larger municipalities were required, by law (2/2011) of Sustainable Economy, to draft a Sustainable Urban Mobility Plan (SUMP) before July 2014, to promote sustainable mobility, showing the urban mobility patterns and proposing improvements on the different modes of transport, with the aim of greater social benefit and lower environmental impact [18]. Therefore, all port-cities in the study have developed its SUMP, and some of them have included, as a specific proposal, a Tourist Mobility Plan (TMP) as in Barcelona, Tarragona and Valencia.

They consider as essential the need to link the maritime stations with all the tourist attractions, commercial and leisure areas of the cities, both through public transport and through other modalities such as cycle-tourism, taxis, tourist buses and pedestrian paths. Thus, the improvement of pedestrian access between the port area and the historic city centre appears as the most common proposal and intervention [19,20]. In addition, the TMP of Barcelona 


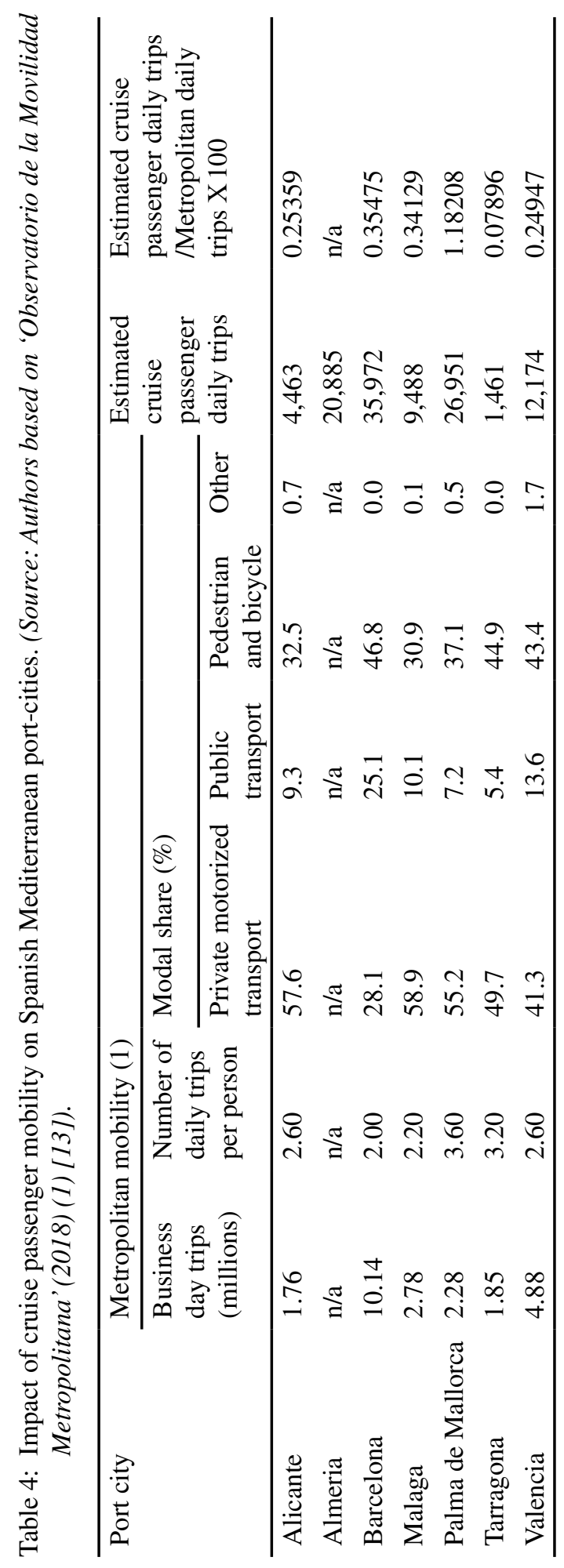




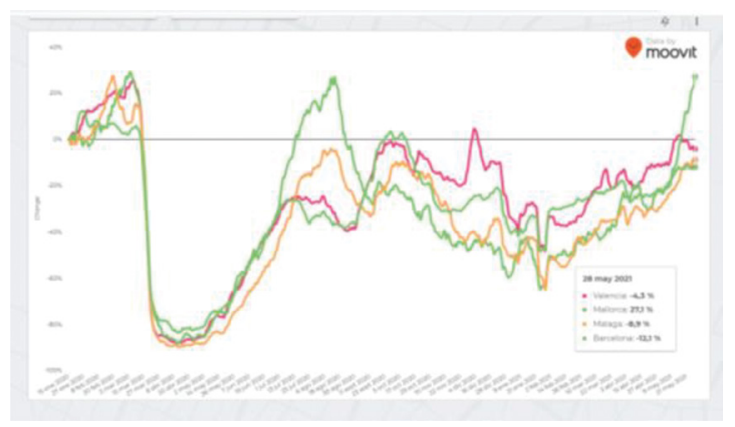

Figure 4: Impact of COVID-19 on the use of public transport systems in Barcelona, Malaga, Mallorca and Valencia. (Source: https://moovitapp.com/insights/es/Moovit_ Insights_\%C3\%8Dndice_de_Transporte_P\%C3\%BAblico-COVID19).

proposes to prioritize traveling by foot rather than the traditional way of visiting the city with tour operators carrying visitors by coach [21].

In case of the city-port of Malaga, in addition to its own SUMP [22], it is taking part in a specific European Project called 'LOCATIONS. Sustainable Mobility in MED tourist destinations' to promote green mobility in cruise destinations. This is co-financed by the European Regional Development Fund and aims to develop and implement Low Carbon Transport Plans (LCTP) with specific measures for cruise passenger flows that will contribute to lowering urban congestion and reducing local pollution. These have been developed in conjunction with the existing mobility plans in seven European port-cities. In the case of Malaga, the LCTP proposes three main lines of action: (1) facilitating mobility and coexistence, promoting pedestrian access to city centre attractions and adopting traffic management schemes before and during cruise ship arrivals; (2) increasing passenger spending in the local economy with the adoption of smart management tools specific to cruise ships, and (3) reducing the carbon footprint and pollution relating to visitor mobility, especially with the use of bicycle sharing schemes and the controlled introduction of personal mobility vehicles. Their positive results are intended to be applied in other port-cities as a catalogue of potential replicating measures organized in 14 modular packages [23].

\subsection{Future trends and expectations}

The cruise industry is a powerful economic sector reflected in a strong union of its international organisation of Cruise Lines International Association (CLIA), and has positive expectations of recovery during the current year. In a recent report it presents itself as a resilient industry and, despite the challenging year in 2020, indicates that 'there is reason for hope and optimism heading into 2021 ', supported by these figures: ' $74 \%$ of cruisers are likely to cruise in the next few years; two out of three cruisers are willing to cruise within a year; and 58\% of international vacationers who have never cruised are likely to cruise in the next few years' [24]. Therefore, this sector expects to return to pre-pandemic figures for cruise shipping in the upcoming months.

In addition, because of falling COVID-19 incidence rates and an increase in vaccinations, a new normality is emerging and the re-opening of services associated with the cruise shipping 
industry is in progress. Spain's maritime authorities recently approved the reopening, and will allow cruise ships to dock in its ports from June 7, hoping to salvage the country's battered tourism sector in time for the summer season [25].

Paradoxically, in general, post-pandemic mobility has returned to previous pollution and congestion levels, and even higher in some cases, as people are opting to use private motorized vehicles instead of public transport due to a fear of infection, therefore pollution/congestion levels are reverting to an unsustainable state [26], and future cruise passenger traffic will aggravate the mobility situation. However, this crisis has also been considered as a potential opportunity for escaping the unsustainable trend in global tourism [27].

\section{CONCLUSIONS}

After a continuous period of cruise activity growth during recent decades, the COVID-19 pandemic has created an extraordinary crisis, which has severely devastated the industry and economies which are heavily dependent on tourism as is the case in Spain.

As has been shown in this and in previous studies, cruise shipping has a significant impact on port-cities, and on the Spanish Mediterranean port-cities in particular. The social impact this creates, with relevance to the proportion of total cruise passengers and the urban population as a primary indicator, appears to be particularly significant in the case of Palma de Mallorca city-port and less so in the case of Barcelona. When we consider the metropolitan area population, the effect is tempered in Barcelona, though not in Mallorca's case, due to its essential orientation towards tourism.

In all the cases studied, except Valencia, the urban centrality of the port-cities, permits a pedestrian-oriented mobility from port cruise terminals, though this creates the problem of overcrowded city centres at peak periods. Nevertheless, the impact on urban mobility is highlighted, analysing the proportion of cruise passenger trips with respect to the metropolitan mobility, appearing again to be higher in the case of Palma de Mallorca, followed by Barcelona, Malaga and Valencia. These impacts will be more limited in port-cities with bigger metropolitan areas and with a highly developed public transport system, as is shown in the well-balanced modal share of Barcelona, and to a lesser degree in Valencia. However, in the case of Mallorca the effects may be greater because of the reduced participation of the public transport system in their modal share which will exacerbate the negative effects of new tourist cruise passenger growth.

The signs of recovery in the use of public transport systems in the port-cities under consideration, especially in Mallorca, the optimistic expectations of the cruise ship industry coupled with the normalization of the sanitary situation is leading to an expected return to prepandemic levels for cruise shipping traffic. This creates a challenging scenario in the Spanish Mediterranean port-cities, where indicated measures for low carbon transport systems, sustainable mobility and new urban mobility management for the future must be explored and implemented.

\section{REFERENCES}

[1] Instituto Nacional de Estadística, Cuenta Satélite del Turismo de España (CSTE), Revisión estadística 2019, Online, available at https://www.ine.es/prensa/cst_2019.pdf (accessed 25 January 2021).

[2] Puertos del Estado, Ministerio de Fomento, Nota de prensa, Online, available at http:// www.puertos.es/Documents/Notas\%20de\%20Prensa/NPFITUR2312019.pdf (accessed 25 January 2021). 
[3] Grindlay, A.L. \& Martínez-Hornos, S., City-Port relationships in Malaga, Spain: effects of the new port proposals on urban traffic. WIT Transactions on the Built Environment, 176, WIT Press: Southampton and Boston, pp. 45-56, 2017. https://doi.org/10.2495/ UT170051

[4] Pallis, A.A., Rodrigue, J.P. \& Notteboom, T.E., Cruises and cruise ports: structures and strategies. Research in Transportation Business \& Management, 13, pp. 1-5, 2014. https://doi.org/10.1016/j.rtbm.2014.12.002

[5] Holland, J., Mazzarol, T., Soutar, G. N., Tapsall, S. \& Elliott, W.A., Cruising through a pandemic: the impact of COVID-19 on intentions to cruise. Transportation Research Interdisciplinary Perspectives, 9, 100328, 2021. https://doi.org/10.1016/j. trip.2021.100328

[6] van Tatenhove, J.P., COVID-19 and European maritime futures: different pathways to deal with the pandemic. Maritime Studies, 20(1), pp. 63-74, 2021. https://doi. org/10.1007/s40152-021-00216-3

[7] Puertos del Estado, Ministerio de Fomento, Estadísticas. Online, available at http://www. puertos.es/es-es/estadisticas/Paginas/estadistica_mensual.aspx (accessed 15 March 2021).

[8] Paniaga, A., 2020, annus horribilis de la industria del crucero. Las consecuencias demoledoras de la pandemia. CruisesNews, 55, Dec. 2020. Online, available at https:// es.calameo.com/cruisesnewsmediagroup/read/0001494317fc15cb0fad1 (accessed 25 January 2021).

[9] Carić, H., Mackelworth, P., Cruise tourism environmental impacts - the perspective from the Adriatic Sea. Ocean \& Coastal Management, 102, pp. 350-363, 2014. http:// dx.doi.org/10.1016/j.ocecoaman.2014.09.008

[10] Galaverna, M., Pozzobon, A., \& Sciutto, G., Transport accessibility and port competitiveness: the case of Savona-Vado. WIT Transactions on the Built Environment, 39, WIT Press: Southampton and Boston, pp. 291-300, 1998. https://www.witpress. com/Secure/elibrary/papers/MAR98/MAR98027FU.pdf

[11] Rosa-Jiménez, C., Perea-Medina, B., Andrade, M.J. \& Nebot, N., An examination of the territorial imbalance of the cruising activity in the main Mediterranean port destinations: effects on sustainable transport. Journal of Transport Geography, 68, pp. 94-101, 2018. https://doi.org/10.1016/j.jtrangeo.2018.02.003

[12] Stefanidaki, E., \& Lekakou, M., Cruise carrying capacity: a conceptual approach. Research in Transportation Business \& Management, 13, pp. 43-52, 2014. https://doi. org/10.1016/j.rtbm.2014.11.005

[13] Ministerio para la Transición Ecológica y el Reto Demográfico, Observatorio de la Movilidad Metropolitana 2018, Online, available at http://www.observatoriomovilidad. es/images/stories/07_jornadas/17_jornada_17_online/INFORME_FINAL_WEB.pdf (accessed 7 April 2021).

[14] Grindlay Moreno, A.L., Ciudades y puertos. Revista Ciudades Instituto Universitario de Urbanística. Universidad de Valladolid, 11, pp. 53-80, 2008. https://doi.org/10.24197/ ciudades. 11.2008

[15] Perea-Medina, B., Rosa-Jiménez, C. \& Andrade, M.J., Potential of public transport in regionalisation of main cruise destinations in Mediterranean. Tourism Management, 74, pp. 382-391, 2019. https://doi.org/10.1016/j.tourman.2019.04.016

[16] Albalate, D., \& Bel, G., Tourism and urban public transport: holding demand pressure under supply constraints. Tourism Management, 31(3), pp. 425-433, 2010. https://doi. org/10.1016/j.tourman.2009.04.011 
[17] Le-Klähn, D.-T., Hall, C.M., Tourist use of public transport at destinations - a review. Current Issue Tourist, 18, pp. 785-803, 2015. http://dx.doi.org/10.1080/13683500.201 4.948812

[18] Ochoa-Covarrubias, G., Molero-Melgarejo, E., Grindlay-Moreno, A.L. \& Falcon Meraz, J.M., Planeación y movilidad como promotores de ciudades saludables en España y México. In Ciudad Sostenible2019. Congreso Iberoamericano para la fundamentación y práctica de la ciudad sostenible. Valencia, 2019. https://rei.iteso.mx/ handle/11117/6238

[19] Ayuntamiento de Alicante, Plan de Movilidad Urbana Sostenible de Alicante, Online, available at https://www.alicante.es/es/documentos/plan-movilidad-urbana-sosteniblealicante-pmus, 2013 (accessed 7 April 2021).

[20] Ayuntamiento de Almería, Plan de Movilidad Urbana Sostenible de Almería, Online, available at https://almeria2030.es/documentos/movilidad/, 2015 (accessed 7 April 2021).

[21] Ajuntament de Barcelona, Pla de Mobilitat Turística (PMT), Online, available at https:// www.barcelona.cat/mobilitat/sites/default/files/ReunioPacteperlaMobilitat09022016_ Mobilitat_Turistica.pdf, 2016 (accessed 7 April 2021).

[22] Ayuntamiento de Málaga, Plan de Movilidad Urbana Sostenible de Málaga, Online, available at https://movilidad.malaga.eu/es/lineas-de-trabajo/plan-especial-de-movilidadurbana-sostenible-pemus/, 2011.

[23] Interreg Mediterranean locations, Sustainable Mobility in MED tourist destinations, available at https://locations.interreg-med.eu/

[24] Cruise Lines International Association(CLIA), 2021 State of the Cruise Industry Outlook. Online, available at https://cruising.org/-/media/research-updates/research/2021-stateof-the-cruise-industry_optimized.ashx (accessed 20 January 2021).

[25] Boletín oficial del estado, Resolución de 27 de mayo de 2021, de la Dirección General de la Marina Mercante, por la que se adoptan medidas sanitarias para los buques de pasaje tipo crucero. 29 de mayo de 2021.

[26] Orro, A, Novales, M. Monteagudo, Á., Pérez-López, J-B. \& Bugarín, M.R., Impact on city bus transit services of the COVID-19 lockdown and return to the new normal: the case of A Coruña (Spain). Sustainability, 12(17), 7206, 2020. http://dx.doi.org/10.3390/ su12177206

[27] Ioannides, D. \& Gyimóthy, S., The COVID-19 crisis as an opportunity for escaping the unsustainable global tourism path, Tourism Geographies, 22:3, pp. 624-632, 2020. https://doi.org/10.1080/14616688.2020.1763445 